\title{
A Review of the Role of Vegetal Ecosystems in $\mathrm{CO}_{2}$ Capture
}

\author{
Giuseppe Di Vita ${ }^{1}$, Manuela Pilato ${ }^{2, *}$, Biagio Pecorino $^{1}$ (D), Filippo Brun ${ }^{3}$ (D) and \\ Mario D'Amico ${ }^{1}$ \\ 1 Department of Agriculture, Food and Environment, University of Catania, Viale Santa Sofia 100, \\ 95123 Catania, Italy; gvitae@hotmail.com (G.D.V.); pecorino@unict.it (B.P.); mariodamico@unict.it (M.D.) \\ 2 Faculty of Business, Law and Sport/Faculty of Humanities and Social Sciences, University of Winchester, \\ Sparkford Road, Winchester SO22 4NR, UK \\ 3 Department of Agricultural, Forest and Food Science, University of Torino, Largo Braccini, 2 Grugliasco, \\ 10095 Torino, Italy; filippo.brun@unito.it \\ * Correspondence: manuela.pilato@winchester.ac.uk; Tel.: +44-01962-827-502
}

Received: 18 August 2017; Accepted: 7 October 2017; Published: 13 October 2017

\begin{abstract}
The reduction of carbon emissions is a worldwide global challenge and represents the objective of many scientists that are trying to modify the role of carbon, turning a problem into an opportunity. The potential of $\mathrm{CO}_{2}$ capture and storage by vegetal species is significant because of their capacity to absorb exceeding carbon emission. The purpose of the present paper is to draw a picture of the role of vegetal ecosystems on carbon fixation by identifying the most significant scientific contributions related to the absorption by vegetal species. In particular the aim of this paper is to examine different forms of $\mathrm{CO}_{2}$ sequestration made by plants and crops involved in reducing greenhouse gas (GHG) emission. Results highlight the important role played by agricultural soils, forests, perennial plants, and algae, looking at the overall reduction of carbon emissions. In addition, results show that some bioenergy crops allow substantial storage of carbon dioxide, providing a significant contribution to climate change mitigation.
\end{abstract}

Keywords: $\mathrm{CO}_{2}$ capture; $\mathrm{CO}_{2}$ storage; agricultural sustainability; carbon fixation; forest plants; bioenergy crops; perennial plants; annual plants

\section{Introduction}

The management of $\mathrm{CO}_{2}$ surpluses, deriving from anthropogenic activities, such as industrial and agricultural emissions, as well as exhaust car gases, has involved several research activities in different scientific fields over the past twenty years [1,2].

The reduction of carbon emissions is a global challenge and a goal for several scientists and academics around the world [1,3-6]. The economic and environmental literature has extensively dealt with possible technological innovations, economic consequences, and environmental benefits, but several points still need to be explored [7-9].

Carbon capture and storage issues can be faced in engineering and technological terms, or can be addressed in biological terms. With this latter regard, the role of vegetal species can be considered the most relevant.

The potential of $\mathrm{CO}_{2}$ capture and storage by vegetal species is significant because of their capacity to absorb exceeding carbon emission. Several experiments that are reviewed frequently have pointed out that plants exposed to high $\mathrm{CO}_{2}$ concentrations grow faster than "plants in ambient air" [10].

Furthermore, the storage of carbon in agricultural and forest ecosystems constitutes a significant opportunity in offsetting carbon dioxide emissions from human activities associated with the current 
climate change and can offer, at the same time, an interesting possibility to differentiate and increase the income of farmers [11,12].

By the end of the last millennium, changes in global agricultural practices that could encompass more than 200 million tons of carbon a year had been attempted by introducing some changes in agricultural management [13]. Agriculture seems, therefore, to be able to contribute to a substantial mitigation to climate change [14-16].

The Intergovernmental Panel on Climate Change reports that forms of conservation tillage could allow for the capture of more than one ton of carbon per hectare per year, while other authors provide figures ranging from a minimum of 3 to a maximum of $500 \mathrm{~kg} \mathrm{C} / \mathrm{ha}$ [17-20].

It was also noted that, despite several analyses carried out on carbon sequestration costs in forestry and agriculture, there are few studies using direct estimates of carbon absorption by vegetal species as a whole. For this reason, there is a lack of any comprehensive review that combines the results of these recent studies carried out on vegetal species.

In light of the paucity of knowledge found in the existing literature, the purpose of the present paper is to draw a picture of the role on the quantitative effects of plants on carbon absorption, identifying the main lines of researches carried out at the international level, and pointing out the most significant scientific contributions related to the $\mathrm{CO}_{2}$ absorption of vegetal species. In particular, the aim of this paper is to examine different forms of $\mathrm{CO}_{2}$ sequestration made by plant crops involved in reducing greenhouse gas (GHG) emission.

The paper is divided into three parts. The first part presents the work assumptions and the methodological issues adopted in the present study. The second one, which relates more closely to the different $\mathrm{CO}_{2}$ capture and storage, reports an overview of main current research on different vegetal ecosystems. One is related to agriculture, forestry, and perennial crops; one is linked to bio-energy crops, and one refers to annual herbaceous species and algae. Finally, the third part discusses and concludes the work.

\section{Methodology}

This research was conducted through an analysis of the studies published in academic journals, in particular, we considered the main databases relating to the following sources: ISI Web of Science, Scopus, Google scholar, Research gate, Blackwell Synergy, CAB Abstracts Oxford Journals Elsevier, Springer and Wiley Interscience. Regarding databases, it seems that Web of Science (WOS) and Scopus are the most widespread databases on different scientific fields and are frequently used to search the literature [21,22]. Until 2004, Web of Science (WOS) was the only international and multidisciplinary database able to obtain the literature of technology, science, medicine, and other fields. However, Elsevier introduced Scopus, which has become a viable alternative [21,23].

Conversely, some researchers have proposed undertaking a subject's specific analysis to find out which databases work best for specific fields or time periods, pointing out that the advantage of one database over another one depends on what exactly is being analyzed, the scientific field, and the period of analysis [21,24-26].

For publications in academic journals, in all databases, a hierarchical search procedure was implemented for the present work. The typed words were as follows: $\mathrm{CO}_{2}$ capture; agricultural sustainability; $\mathrm{CO}_{2}$ management models; agricultural greenhouse gas (GHG) emission. This procedure yielded about 2100 results (including those present in different databases). Among all of these, in order to determine the relevance of the paper, only those strictly related to the hypothesis of the present research were extracted, for which the full text version was obtained. Though we cannot ascertain with absolute certainty that we have located all relevant studies, 56 works of potential relevance were identified. 


\section{The Contribution of Agriculture, Forest, and Perennial Crops in $\mathrm{CO}_{2}$ Fixation}

Cropland, having been depleted of their original stock of carbon over decades, possesses a remarkable capacity to absorb $\mathrm{CO}_{2}$. The most appropriate management practices to increase carbon capture in agricultural soils vary locally, depending on both environmental and socio-economic factors.

In mild regions, key strategies identified by experts include a progressive reduction of fallow land and an increase in the use of perennial fodder crops (including nitrogen-fixing species) in rotation with cereal crops, the burying of crop residues, and the minimization of machining operations (no-tillage).

In North America and Europe, the conversion of marginal arable crops into a permanent vegetation coverage protects soils subject to erosion, improves landscape, and reduces agricultural surpluses, while offering additional opportunities for increasing carbon capture [16,17].

The carbon capture rate in agricultural soils, through the adoption of recommended technologies, depends on soil structure, rainfall, temperature, farming systems, cultivation, and soil management. Strategies to increase soil carbon pools include the restoration of soil and the regeneration of woods, no-tillage, the burial of crop residues from the nutrients, the use and typology of fertilization, improved grazing, water conservation and harvesting, efficient irrigation, agro-forestry practices, and energy growing crops on spare lands [18-20]. Another study highlights the importance of cultivation operations in carbon mitigation potential, showing a full account of agricultural GHG emissions costs. This analysis-conducted within some temperate and tropical systems-demonstrates the importance of quantifying all mitigation options, such as the rational use of nitrogen fertilizers, agricultural liming, fuel consumption, $\mathrm{N}_{2} \mathrm{O}$ emissions, and $\mathrm{CH}_{4}$ flows in terms of potential global warming. The evaluation of all potential sources responsible for GHG emissions becomes crucial to better identify and determine the appropriate management practices in agriculture [27].

The capture of carbon realized in agricultural land could potentially offset the emissions caused by fossil fuels, intercepting 0.4 to 1.2 tons of carbon per year, corresponding to percentages from 5 to $15 \%$ of global emissions from fossil fuels [18]. This research also confirms that the contribution of agriculture to the reduction of $\mathrm{CO}_{2}$ emissions is mainly due to its release of carbon in the soil and to the simultaneous production of nitrogen protoxide $\left(\mathrm{N}_{2} \mathrm{O}\right)$ and methane $\left(\mathrm{CH}_{4}\right)$.

The carbon capture in the depleted soils, with reference to the organic component, is a well-known strategy to mitigate the accumulation of $\mathrm{CO}_{2}$ in the atmosphere. It was estimated that an increase of 1 ton of soil carbon pool of degraded cropland can increase crop yield from 20 to $40 \mathrm{~kg}$ per hectare for wheat, 10 to $20 \mathrm{~kg} / \mathrm{ha}$ for corn, and from 0.5 to $1 \mathrm{~kg} / \mathrm{ha}$ for peas [18].

Regarding to forest and perennial plants, as highlighted in recent researches conducted in Canada, the reforestation of agricultural lands can play an important role in the overall reduction of $\mathrm{CO}_{2}$ emissions policy. In this sense, the use of marginal agricultural land for forest purposes has considerable economic and environmental potential [28].

In a recent study, a control model was used in order to determine the optimal level of afforestation in Western Canada to meet its obligations under the Kyoto Protocol. The results indicate that planting fast-growing trees on less productive agricultural lands is important for carbon absorption dynamics [28].

However, in a parallel study, authors remark that specific public incentives are necessary in order to promote such plantations on a large scale. In fact, economic analyses indicate that, after the conversion of forest to agricultural lands, the associated cost to reforestation projects constitute a significant obstacle to the owners, although these costs are lower than those related to the reduction of carbon emissions through other forms of $\mathrm{CO}_{2}$ capture [29].

Another study highlighted the critical features of the methodologies used for assessing the climate effects of forest biomass used for energy purposes by underlying how previous research had not taken into account the use of forest carbon stock in the determination of GHG emission where the demand for energy was absent [30]. In the absence of such demand, forests can continue to grow or be assigned to the production of timber products. Therefore, in order to achieve a correct balance emission of carbon sequestration, it is necessary to evaluate the stored carbon from the forest production, taking into 
consideration the scenarios of non-harvesting and including the forest biomass aimed at obtaining bioenergy [30].

\section{The Role of Bioenergy Crops in $\mathrm{CO}_{2}$ Storage}

Referring to $\mathrm{CO}_{2}$ emissions, in the context of single agricultural productions, bioenergies have also been studied by scholars, researchers, and academics. In this field, bioenergy industries represent valuable means in order to promote the development of extensive agricultural areas destined for cereals crops such as wheat and barley, and marginal and uncultivated surfaces offer ideal soils for vegetal cultivations suitable for the production and conversion of biomass plants and their crop residues to the production of energy [31-33].

According to recent studies thanks to bio-energy crops, a significant contribution to climate change mitigation should be originated. However, bioenergy is not necessarily "carbon neutral" because of the emissions of $\mathrm{CO}_{2}, \mathrm{~N}_{2} \mathrm{O}$, and $\mathrm{CH}_{4}$ during the production cycle. In fact, such emissions could reduce or even eliminate the reduction of the $\mathrm{CO}_{2}$ of replaced fossil fuels. Nowadays, scientists agree that these GHGs must be included in calculating the carbon footprint of different bioenergy crops, taking into account soil conditions and agronomic management practices [34-36].

On the basis of what previously highlighted and in order to have a better storage of carbon dioxide, the choice of the most suitable crop becomes crucial. In this regard, some scholars have developed a multi-criteria analysis methodology (multi-attribute type) in order to assess the territorial aptitude for the development of the biomass energy industry. Using environmental data, such as morphological characteristics, climate, land use, and soil, this methodology develops a geographic database and defines criteria and constraints related to the suitability of the crop, with particular reference to sunflowers, in a GIS environment [31].

In this way, the authors offer an innovative approach to the definition of territorial aptitude, expressed through land suitability map, subdividing the area of investigation into classes with different levels of territorial vocation, taking into account the spatial heterogeneity [37].

Some authors have investigated the agricultural and environmental limitations and the greenhouse gas balance of the growing number of European bioenergy crops such as Miscanthus and poplar or willow short rotation coppice plantations. Although these crops account for only $3 \%$ of the current European bioenergy production, they are able to reduce emissions, since these species emit $40-99 \%$ less $\mathrm{N}_{2} \mathrm{O}$ compared to annual conventional crops. This significant result is due to a lower need of fertilizers, as well as a higher efficiency in nitrogen fixation. The best results are obtained cultivating agricultural soils, with neither positive nor negative effects on the carbon balance when they are planted on land that was previously used as pastures [31]. Even though perennial energy crops have a high potential to mitigate greenhouse gas effects, numerous agronomic and economic constraints still need to be overcome [34].

A study on tape grass (Phalaris arundinaceae L.) allowed for an evaluation of the absorption of carbon dioxide variations $\left(\mathrm{CO}_{2}\right.$ per the type of cultivation) taking into account the physical-chemical characteristics of the soil (organic matrix, etc.) and its ecosystem. Through a special technique, the eddy covariance, the total absorption of $\mathrm{CO}_{2}$ was measured over four years in a tape grass cultivation on some peat bogs of Eastern Finland. This study has permitted the recognition that, during wet seasons, with moderate temperatures, with high humidity of the soil surface, and in the presence of low evaporation phenomena, a greater absorption of $\mathrm{CO}_{2}$ is stimulated. On the contrary, during dry seasons, due to soil humidity and atmospheric stress, the photosynthetic activity is severely restricted. The same study found that the absorption of $\mathrm{CO}_{2}$ appears positively correlated with soil humidity, air temperature, and inversely with any vapor pressure deficit. The total ecosystem respiration grows with an increase in soil temperature, but drops with a rise in soil moisture [38].

At the same time, the growing interest in biofuel trade between developed and developing countries has stimulated a debate around the world, with particular attention to issues such as economic outlook for rural populations, subsidies, and food versus fuel trade-offs. However, little is 
known about incentive systems that can be applied in developing countries in order to promote large-scale mechanized agricultural practices for the improvement of profitable crops. Such approaches often exclude small farmers from the participation in the emerging biofuel market, worsening poverty, and social exclusion in broad segments of the rural population. In this sense, a recent study, based on qualitative and technical data, described the ethanol productions aimed at obtaining biodiesel. Such a study showed that the pressure carried out by international markets in order to improve economic efficiency of agricultural biodiesel production can cause an erosion of the economic systems of rural populations, even if, at the same time, it can encourage development opportunities, through an income differentiation for small farmers [39-41].

Nowadays, transport is almost exclusively based on petroleum fuels and they consume about $30 \%$ of worldwide fossil fuels. Based on the principle of sustainable development, a modern society should conserve non-renewable energy sources and attempt to replace them with energy from renewable sources.

The gradual depletion of fossil fuel reserves and the associated environmental impacts are the two main reasons that the use of alternative fuels is considered in the transport sector. Fuels derived from biomass plant, called "biofuels," are potentially renewable, and sufficiently similar to fossil fuels. Therefore, biomasses seem to be a promising alternative to fossil fuels, even in the short term.

Carbon dioxide $\left(\mathrm{CO}_{2}\right)$ deriving from biomass combustion has traditionally been considered neutral, in terms of climate, because it has always been tacitly accepted that the released $\mathrm{CO}_{2}$ equals the amount of sequestered $\mathrm{CO}_{2}$ [41]. However, this convention, widely adopted in life cycle assessment (LCA) studies of bioenergy systems, underestimates the climate impact of bioenergy. In fact, in addition to permanent losses of carbon and their related $\mathrm{CO}_{2}$ emissions, there are temporary $\mathrm{CO}_{2}$ emissions in the atmosphere before $\mathrm{CO}_{2}$ is captured by the plants. These temporary emissions may contribute to global warming as well [42-44].

A recent paper has put forward a method for estimating the climate impact of $\mathrm{CO}_{2}$ emissions by biomass combustion. This method uses the $\mathrm{CO}_{2}$ impulse response functions (IRFs) in the development of decay functions of atmospheric $\mathrm{CO}_{2}$ emissions from burning biomass. The contribution to global warming is then quantified through a global warming potential (GWP) index which is expressed as a function of biomass rotation period and can be applied to $\mathrm{CO}_{2}$ emissions of all tree species used in biomass plantations, from fast growing annual crops to slow growing ones [42].

\section{Other Annual Plants}

This last subsection concerns the role of aquatic plants and cereals carbon assimilation.

Algae are an interesting source of biomass energy because they compete neither with food crops nor with feed crops and have higher energy yields compared to many terrestrial crops. Despite these benefits, the LCA of algae cultivation has not been sufficiently explored, compared to conventional crops.

In this regard, a recent contribution evaluated the LCA of algae production using a stochastic model [45]. The results were then compared with those of other agricultural crops, such as savoy cabbage and corn, and indicated that conventional crops had a lower environmental impact than algae, in terms of energy consumption, greenhouse gas emissions, and water, regardless of the place of cultivation [45]. On the other hand, algae have positive impacts in terms of the total use of agricultural land and potential eutrophication. The biggest environmental impact of their cultivation is linked to productive aspects, such as an increased demand of fertilizers. In order to reduce these negative impacts, the model was extended to include three different effluents of municipal wastewater containing nitrogen and phosphorus. The results showed that such use leads to the significant reduction of environmental burdens associated with algae cultivation, and it can make such cultivation, compared to other traditional crops, more beneficial for the environment [45].

Further studies have taken into account the metabolism of some microalgae and their carbon fixation capacity, by subtracting carbon dioxide to the atmosphere. For this purpose, the analysis of 
growth parameters were measured taking into account biomass composition and nutrient balance. Several microalgae were used in the experiment, being suitable for mass cultivation: Dunaliella tertiolecta SAD-13.86, Chlorella vulgaris LEB-104, Spirulina platensis LEB-52, and Botryococcus braunii SAG-30.81. The overall fixation rate of carbon dioxide was recorded by B. braunii followed by S. platensis, D. tertiolecta, and C. vulgaris (respectively 496.98, 318.61, 272.4, and $251.64 \mathrm{mg} / \mathrm{L}$ per day) [46].

The fixed carbon dioxide has mainly been used for microalgal biomass production and, in particular, for each of the four microalgae, accumulated nutrients were analyzed: such as nitrogen, phosphorus (calcium for D. tertiolecta), potassium, and magnesium. The evaluation of biomass composition leads the research to detect a predominance of protein and a high amount of lipids, especially in D. tertiolecta and B. braunii [46].

With regard to some annual species, it was shown that the climatic conditions of Virginia coastal lowland can cause a high annual $\mathrm{CO}_{2}$ fixation [47]. Furthermore, there is a possibility of seizing a significant amount of carbon and, at the same time, improving the soil quality, excluding crop tillage [8]. This study examined samples collected from 63 sites in productive sectors with a rotation of corn (Zea mays L.), wheat (Triticum aestivum L.), barley (Hordeum vulgare L.), and soybean (Glysine max L.) in three different types of soils-Bojac (coarse-loamy, mixed, semiactive, thermal Typic Hapludults), Altavista (fine-loamy, mixed semiactive, thermal Aquic Hapludults), and Kempsville (fine-loamy, siliceous, subactive, thermal Typic Hapludults)—subjected to no-tillage management. The carbon assimilation rate in soils not subjected to processing were thus measured, showing a correlation between high rates of carbon assimilation and improvements related to the quality of soil not subjected to processing [18].

\section{Discussion and Conclusions}

The reduction of carbon emissions is a worldwide global challenge and represents the objective of scientists that are trying to modify the role of carbon, turning a problem into an opportunity. The need for sustainable agriculture and agro-food products has in fact become a priority for several developed countries. With this regard, the present study highlighted current research topics on the $\mathrm{CO}_{2}$ capture and storage in farming, food, and energy sectors through the main up-to-date $\mathrm{CO}_{2}$ emission management models. As illustrated, 56 works of potential relevance were identified for this paper. The main aim of this work, in terms of future prospects and challenges, was to examine different forms of carbon sequestration made by plants and ecosystems potentially involved in reducing greenhouse gas emission.

Firstly, as previously discussed, cropland, having been over decades depleted of their original stock of carbon, possesses a remarkable capacity to absorb $\mathrm{CO}_{2}$. The most appropriate management practices to increase carbon capture in agricultural soils vary locally, depending on both environmental and socio-economic factors. Moreover, results demonstrated that, within some temperate and tropical systems, it is essential to quantify all mitigation options such as the rational use of nitrogen fertilizers, agricultural liming, fuel consumption, $\mathrm{N}_{2} \mathrm{O}$ emissions, and $\mathrm{CH}_{4}$ fluxes in terms of global warming potential. The evaluation of all potential sources responsible for greenhouse gas emissions has become extremely important because appropriate management practices in agriculture can be identified and determined.

Moreover, forests can significantly reduce the overall reduction of carbon emissions. In this sense, the use of marginal agricultural land for forest purposes has considerable economic and environmental potential.

The review also reveals that, in the absence of demand for bioenergy forests, it can continue to grow or be assigned to the production of timber products. In line with this, in order to achieve a proper emission balance and carbon capture, it is necessary to evaluate the stored carbon from forest production, taking into consideration the scenarios of non-harvesting and recording the forest biomass destined to obtaining bioenergy. That said, recent studies related to the use of bio-energy crops should 
be able to significantly contribute to climate change mitigation. However, as discussed previously, bioenergy is not necessarily "carbon neutral" because, during the crop production cycle, emissions of $\mathrm{CO}_{2}, \mathrm{~N}_{2} \mathrm{O}$, and $\mathrm{CH}_{4}$ can reduce or almost completely eliminate the use of containment, resulting in the $\mathrm{CO}_{2}$ of replaced fossil fuels. Therefore, these greenhouse gases must be included in calculations of the carbon footprint of different bioenergy crops, taking into account soil conditions and agronomic management practices. Moreover, if the storage of carbon dioxide is to be improved, the choice of the most suitable crop must become fundamental. In this regard, some scholars have showed the importance of a territorial vocation with respect to the development of the biomass energy industry.

In the interim, the growing interest in trade biofuels between developed and developing countries has stimulated a debate around the world, focusing its attention on issues such as the economic outlook for rural populations, subsidies, and food for fuel crisis. Secondly, algae are an interesting source of biomass energy because they do not compete with food crops and have higher energy yields compared to terrestrial crops. However, the life cycle of algae cultivation, compared with that of conventional crops, has not been sufficiently explored. In this regard, a recent study evaluated the impact of the production of algae (life cycle) by comparing them with those of other agricultural annual crops such as savoy cabbage and corn. The results indicated that conventional crops have a lower environmental impact than algae in terms of energy consumption, greenhouse gas emissions, and water, regardless of place of cultivation. Nevertheless, algae cover an important role in carbon fixation by subtracting carbon dioxide to the atmosphere, reducing the environmental burdens associated with greenhouse gases.

Thirdly, even the EU's agricultural policies have highlighted dynamics times in decreasing carbon footprint and recognize the possibility of a reduction in profit margins by farmers, supporting the productive and economic efforts [48]. Therefore, evaluating the introduction of new agricultural and forest policy measures, should be carefully assessed the positive and negative effects that such measures exert on the environment. Nevertheless, when a new project starts or when a new agricultural and forestry policy measure is applied, it needs to take into account all costs and all economic and social environmental benefits. It is also necessary to consider the assessment of welfare effects; parallel estimations related to economic benefits in terms of promoting economic growth per se (production of biomass for bioenergy, supply raw materials, production of forestry products, increasing employment, protection of the territory, etc.), and finally taking into account the environmental and ecological characteristics [49].

In this direction, current policies of the European Union, through the Common Agricultural Policy, are pursuing objectives to ensure viable food production linked to the sustainable use of natural resources, as well as to act for the climate and contribute to a balanced territorial development. The realization of this objective requires creating, sharing, and applying new multi-level knowledge, and several actions, such as testing new crops and cultivars, the introduction of new technologic processes linked to major water use efficiency (adopting drip and sub-irrigation), the adoption of agricultural practices that are less carbon intensive, and the enhancement of agronomic productivity per unit consumption of C-based, must be taken. Finally, the management of agricultural practices should be addressed to optimize the use of soil, as a whole, and to reduce energy and resource consumption, taking into account different agricultural ecosystems from a holistic and multidisciplinary approach, thus reinforcing the role of endogenous resources in combination with public initiatives [18,50-56].

Acknowledgments: This work was financially supported through the project "BIO4BIO_Biomolecular and Energy assessment of residual biomass from Agroindustry and Fishing Industry" led by the Cluster Sicily Agrobio and Fishing Industry and funded by the Italian Research Fund (PONR\&C2007-2013, DD713/Ric.-PON02 004513362376) and the "Agronomic innovations and economic analysis for the production of biomass for energy and economic evaluation of natural capital" - Call for departmental research projects 2016-2018-UNICT; Project leader: Gioacchino Pappalardo.

Conflicts of Interest: The authors declare no conflict of interest. 


\section{References}

1. Gibbins, J.; Chalmers, H. Carbon capture and storage. Energy Policy 2008, 36, 4317-4322. [CrossRef]

2. Cembalo, L.; Caracciolo, F.; D'Amico, M. Managing a venture in bio-energy supply chain: An operational approach. Qual. Access Success 2016, 17, 118-123.

3. Metz, B.; Davidson, O.; De Coninck, H.; Loos, M.; Meyer, L. Carbon Dioxide Capture and Storage; IPCC Special Report; IPCC: Geneva, Switzerland, 2005.

4. Petrescu, L.; Bonalumi, D.; Valenti, G.; Cormos, A.M.; Cormos, C.C. Life Cycle Assessment for supercritical pulverized coal power plants with post-combustion carbon capture and storage. J. Clean. Prod. 2017, 157, 10-21. [CrossRef]

5. Zhao, B.; $\mathrm{Su}$, Y.; Tao, W.; Li, L.; Peng, Y. Post-combustion $\mathrm{CO}_{2}$ capture by aqueous ammonia: A state-of-the-art review. Int. J. Greenh. Gas Control 2012, 9, 355-371. [CrossRef]

6. Zhuang, Q.; Clements, B.; Li, Y. From ammonium bicarbonate fertilizer production process to power plant $\mathrm{CO}_{2}$ capture. Int. J. Greenh. Gas Control 2012, 10, 56-63. [CrossRef]

7. Rubin, E.S.; Rao, A.B.; Chen, C. Comparative assessments of fossil fuel power plants with $\mathrm{CO}_{2}$ capture and storage. In Proceedings of the 7th International Conference on Greenhouse Gas Control Technologies (GHGT-7), Vancouver, BC, Canada, 5 September 2004; pp. 285-293.

8. Di Vita, G. Sustainability scenarios of current agricultural practices. The role of carbon: Turning a problem into an opportunity. Ann. Agric. Crop Sci. 2016, 1, 1-2.

9. Duan, H.B.; Fan, Y.; Zhu, L. What's the most cost-effective policy of $\mathrm{CO}_{2}$ targeted reduction: An application of aggregated economic technological model with CCS? Appl. Energy 2013, 112, 866-875. [CrossRef]

10. Kimball, B.A. Carbon dioxide and agricultural yield: An assemblage and analysis of 430 prior observations. Agron. J. 1983, 75, 779-788. [CrossRef]

11. Manley, J.; van Kooten, G.C.; Moeltner, K.; Johnson, D.W. Creating carbon offsets in agriculture through no-till cultivation: A meta-analysis of costs and carbon benefits. Clim. Chang. 2005, 68, 41-65. [CrossRef]

12. Spargo, J.T.; Alley, M.M.; Follett, R.F.; Wallace, J.V. Soil carbon sequestration with continuous no-till management of grain cropping systems in the Virginia coastal plain. Soil Tillage Res. 2008, 100, 133-140. [CrossRef]

13. Lal, R.; Kimble, L.M.; Follett, R.F.; Cole, C.V. The Potential of U.S. Cropland to Sequester C and Mitigate the Greenhouse Effect; Ann Arbor Press: Chelsea, MI, USA, 1998.

14. Irons, R.; Sekkapan, G.; Panesar, R.; Gibbins, J.; Lucquiard, M. CO 2 Capture Ready Plants; IEA Greenhouse R\&D Programme, Orchard Business Centre: Stoke Orchard, UK, 2007.

15. Di Vita, G.; Chinnici, G.; D'Amico, M. Sustainability of olive oil production in Sicilian marginal agricultural areas. Qual. Access Success 2015, 1, 118-125.

16. Pilato, M.; Di Vita, G.; D'Amico, M. Carbon dioxide capture from agricultural biomass: An overview on the assessment methods. Qual. Access Success 2017, 18, 334-341.

17. IPCC (Intergovernmental Panel on Climate Change). Land Use, Land-Use Change, and Forestry; Cambridge University Press: New York, NY, USA, 2000.

18. IPCC (Intergovernmental Panel on Climate Change). Climate Change 2001: The Scientific Basis; Cambridge University Press: Cambridge, UK, 2001.

19. Uri, N.D. Conservation practices in US agriculture and their impact on carbon sequestration. Environ. Monit. Assess 2001, 70, 323-344. [CrossRef] [PubMed]

20. Follett, R.F. Soil management concepts and carbon sequestration in cropland soils. Soil Tillage Res. 2001, 61, 77-92. [CrossRef]

21. Arezoo Aghaei, C.; Hadi, S.; Melor, M.Y.; Hadi, F.; Masood, F.; Maryam, F.; Nader, A.I. A comparison between two main academic literature collections: Web of science and scopus databases. Asian Soc. Sci. 2013, 9. [CrossRef]

22. Guz, A.N.; Rushchitsky, J.J. Scopus: A system for the evaluation of scientific journals. Int. Appl. Mech. 2009, 45, 351-362. [CrossRef]

23. Vieira, E.S.; Gomes, J.A.N.F. A comparison of Scopus and Web of Science for a typical university. Scientometrics 2009, 81, 587-600. [CrossRef]

24. Bar-Ilan, J.; Levene, M.; Lin, A. Some measures for comparing citation databases. J. Informetr. 2007, 1, 26-34. [CrossRef] 
25. Bakkalbassi, N.; Bauer, K.; Glover, J.; Wang, L. Three options for citation tracking: Google Scholar, Scopus and Web of Science. Biomed. Digit. Libr. 2006, 3, 7. [CrossRef] [PubMed]

26. Neuhaus, C.; Daniel, H.D. Data sources for performing citation analysis: An overview. J. Doc. 2008, 64, 193-210. [CrossRef]

27. Paustian, K.A.O.J.H.; Andrén, O.; Janzen, H.H.; Lal, R.; Smith, P.; Tian, G.; Woomer, P.L. Agricultural soils as a sink to mitigate $\mathrm{CO}_{2}$ emissions. Soil Use Manag. 1997, 13, 230-244. [CrossRef]

28. Fagarazzi, C.; Tirinnanzi, A.; Cozzi, M.; Di Napoli, F.; Romano, S. The forest energy chain in Tuscany: Economic feasibility and environmental effects of two types of biomass district heating plant. Energies 2014, 7, 5899-5921. [CrossRef]

29. Lal, R. Soil carbon sequestration impacts on global climate change and food security. Science 2004, 304, 1623-1627. [CrossRef] [PubMed]

30. Chinnici, G.; D’Amico, M.; Rizzo, M.; Pecorino, B. Analysis of biomass availability for Energy use in Sicily. Renew. Sustain. Energy Rev. 2015, 52, 1025-1030. [CrossRef]

31. Pergola, M.; D’Amico, M.; Celano, G.; Palese, A.M.; Scuderi, A.; Di Vita, G.; Pappalardo, G.; Inglese, P. Sustainability evaluation of Sicily's lemon and orange production: An energy, economic and environmental analysis. J. Environ. Manag. 2013, 128, 674-682. [CrossRef] [PubMed]

32. Robertson, G.P.; Grace, P.R. Greenhouse gas fluxes in tropical and temperate agriculture: The need for a full-cost accounting of global warming potentials. In Tropical Agriculture in Transition-Opportunities for Mitigating Greenhouse Gas Emissions; Springer: Dordrecht, The Netherlands, 2004; pp. 51-63.

33. Van Kooten, G.C. Economic dynamics of tree planting for carbon uptake on marginal agricultural lands. Can. J. Agric. Econ. 2000, 48, 51-65. [CrossRef]

34. Van Kooten, G.C.; Shaikh, S.L.; Suchánek, P. Mitigating climate change by planting trees: The transaction costs trap. Land Econ. 2002, 78, 559-572. [CrossRef]

35. Ter-Mikaelian, M.T.; Colombo, S.J.; Chen, J. The burning question: Does forest bioenergy reduce carbon emissions? A review of common misconceptions about forest carbon accounting. J. For. 2015, 113, 57-68. [CrossRef]

36. Cembalo, L.; Caracciolo, F.; Migliore, G.; Lombardi, A.; Schifani, G. Bioenergy chain building: A collective action perspective. Agric. Food Econ. 2014, 2, 1-13. [CrossRef]

37. Romano, S.; Cozzi, M.; Napoli, F.D.; Viccaro, M. Building agro-energy supply chains in the Basilicata region: Technical and economic evaluation of interchangeability between fossil and renewable energy sources. Energies 2013, 6, 5259-5282. [CrossRef]

38. Cembalo, L.; Pascucci, S.; Tagliafierro, C.; Caracciolo, F. Development and management of a bio-energy supply chain through contract farming. Int. Food Agribus. Manag. Rev. 2014, 17, 33.

39. Don, A.; Osborne, B.; Hastings, A.; Skiba, U.; Carter, M.S.; Drewer, J.; Zenone, T. Land-use change to bioenergy production in Europe: Implications for the greenhouse gas balance and soil carbon. GCB Bioenergy 2012, 4, 372-391. [CrossRef]

40. Dale, B.E.; Sibilla, F.; Fabbri, C.; Gattoni, P.; Bozzetto, S. Biogas done right: An innovative new system is commercialized in Italy. Biofuels Bioprod. Biorefin. 2016, 10, 341-345. [CrossRef]

41. Manetto, G.; Pecorino, B.; Selvaggi, R. Sustainability of a consortial anaerobic fermentation plant in Sicily. Qual. Access Success 2016, 17, 106-112.

42. Lupia, F.; Alfano, V.; Colucci, F.; Colonna, N. Analisi territoriale multicriterio per lo sviluppo di una filiera bioenergetica. In Proceedings of the Atti della 11a Conferenza Nazionale delle Associazioni Scientifiche per le Informazioni Territoriali e Ambientali-ASITA, Torino, Italy, 6 November 2007.

43. Shurpali, N.J.; Hyvönen, N.P.; Huttunen, J.T.; Clement, R.J.; Reichstein, M.; Nykänen, H.; Martikainen, P.J. Cultivation of a perennial grass for bioenergy on a boreal organic soil-carbon sink or source? GCB Bioenergy 2009, 1, 35-50. [CrossRef]

44. Hall, J.; Matos, S.; Severino, L.; Beltrão, N. Brazilian biofuels and social exclusion: Established and concentrated ethanol versus emerging and dispersed biodiesel. J. Clean. Prod. 2009, 17, S77-S85. [CrossRef]

45. Bentivoglio, D.; Finco, A.; Piedade Bacchi, M.R. Interdependencies between biofuel, fuel and food prices: The case of the Brazilian ethanol market. Energies 2016, 9, 464. [CrossRef]

46. Shikida, P.F.A.; Finco, A.; Cardoso, B.F.; Bentivoglio, D.; Rasetti, M.A. Comparison between ethanol and biodiesel production: The Brazilian and European experiences. Energy 2014, 27, 25-53. 
47. Cherubini, F.; Peters, G.P.; Berntsen, T.; Strømman, A.H.; Hertwich, E. $\mathrm{CO}_{2}$ emissions from biomass combustion for bioenergy: Atmospheric decay and contribution to global warming. CB Bioenergy 2011, 3, 413-426. [CrossRef]

48. Ballarin, A.; Vecchiato, D.; Tempesta, T.; Marangon, F.; Troiano, S. Biomass energy production in agriculture: A weighted goal programming analysis. Energy Policy 2011, 39, 1123-1131. [CrossRef]

49. De Luca, A.I.; Falcone, G.; Iofrida, N.; Strano, A.; Gulisano, G. Life cycle methodologies to improve agri-food systems sustainability. Riv. Stud. Sosten. 2015, 135-150. [CrossRef]

50. Clarens, A.F.; Resurreccion, E.P.; White, M.A.; Colosi, L.M. Environmental life cycle comparison of algae to other bioenergy feedstocks. Environ. Sci. Technol. 2010, 44, 1813-1819. [CrossRef] [PubMed]

51. Sydney, E.B.; Sturm, W.; de Carvalho, J.C.; Thomaz-Soccol, V.; Larroche, C.; Pandey, A.; Soccol, C.R. Potential carbon dioxide fixation by industrially important microalgae. Bioresour. Technol. 2010, 101, 5892-5896. [CrossRef] [PubMed]

52. Wu, L.; Wood, Y.; Jiang, P.; Li, L.; Pan, G.; Lu, J.; Enloe, H.A. Carbon sequestration and dynamics of two irrigated agricultural soils in California. Soil Sci. Soc. Am. J. 2008, 72, 808-814. [CrossRef]

53. Cembalo, L.; Del Giudice, T.; Caracciolo, F. $\mathrm{CO}_{2}$ Emission in the Fresh Vegetables Chains: A Meta-Analysis. Available online: http://centmapress.ilb.uni-bonn.de/ojs/index.php/proceedings/article/view/254 (accessed on 13 October 2017).

54. Lundgren, T.; Marklund, P.O. Assessing the welfare effects of promoting biomass growth and the use of bioenergy. Clim. Chang. Econ. 2013, 4, 135003. [CrossRef]

55. De Luca, A.I.; Molari, G.; Seddaiu, G.; Toscano, A.; Bombino, G.; Ledda, L.; Vittuari, M. Multidisciplinary and innovative methodologies for sustainable management in agricultural systems. Environ. Eng. Manag. J. 2015, 14, 1571-1581.

56. Carlsson-Kanyama, A. Food consumption patterns and their influence on climate change: Greenhouse gas emissions in the life-cycle of tomatoes and carrots consumed in Sweden. Ambio 1998, 27, 528-534.

(C) 2017 by the authors. Licensee MDPI, Basel, Switzerland. This article is an open access article distributed under the terms and conditions of the Creative Commons Attribution (CC BY) license (http:// creativecommons.org/licenses/by/4.0/). 